LETTERS

\title{
Involvement of the omentum in Wegener's granulomatosis
}

\author{
E J A Kroot, C L P Mak, R U Boelhouwer, M P C Middelkoop, A Dees
}

Ann Rheum Dis 2003;62:1238-1239. doi: 10.1136/ard.2003.012310

A 70 year old male patient was admitted to the outpatient clinic because of chronic fatigue, weight loss, generalised joint aching, arthritis of the ankles, and renal insufficiency. His medical history was unremarkable. At physical examination, increased central venous pressure, subfebrile temperature of $38.4^{\circ} \mathrm{C}$, tender and swollen ankles, and painful flexion and extension were observed. Laboratory investigation showed an erythrocyte sedimentation rate of $70 \mathrm{~mm} / \mathrm{lst} \mathrm{h}$, haemoglobin $5.1 \mathrm{mmol} / \mathrm{l}$, leucocytes $18.6 \times$ $10^{9} / \mathrm{l}$, eosinophils $670 \times 10^{6} / \mathrm{l}$, serum creatinine $369 \mu \mathrm{mol} / \mathrm{l}$, urea $18.0 \mathrm{mmol} / \mathrm{l}$, and urine sediment with 20-50 erythrocytes, $0-5$ leucocytes, and several casts of the urinary tract epithelial lining. Positive tests for antineutrophil cytoplasmic antibodies with a cytoplasmic pattern (c-ANCA) and antigenic specificity for proteinase 3 were found. A renal biopsy disclosed focal necrotising intra- and extracapillary glomerulonephritis, with crescents fitting a diagnosis of Wegener's granulomatosis (fig 1). Because of rapid renal and pulmonary deterioration immune suppressive treatment and dialysis were started clinically. However, during the initial stage of this treatment, the patient suddenly experienced severe abdominal pain.

Emergent radiological examination by computed tomographic scan showed diffuse intra-abdominal bleeding of unknown origin. Laparotomy revealed a massive intraabdominal loss of blood. Diffuse intraperitoneal bleeding was uncovered, especially in the greater omentum, which had to be excised. Gastrointestinal perforations were not seen. Histological examination of the resected omentum diagnosed focal necrotising vasculitis of the venules of the omentum (fig 2). After this the patient soon recovered, and treatment with corticosteroids and cyclophosphamide was continued for 18 months. From that time cyclophosphamide could be discontinued and the patient has been followed up to the present without exacerbations of Wegener's granulomatosis.

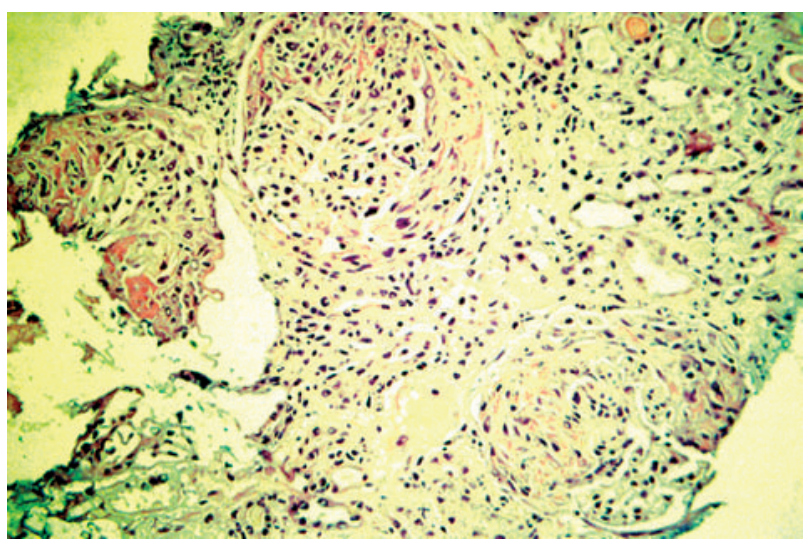

Figure 1 Renal biopsy: focal necrotising intracapillary and extended extracapillary glomerulonephritis with crescents, fitting a diagnosis of Wegener's granulomatosis.

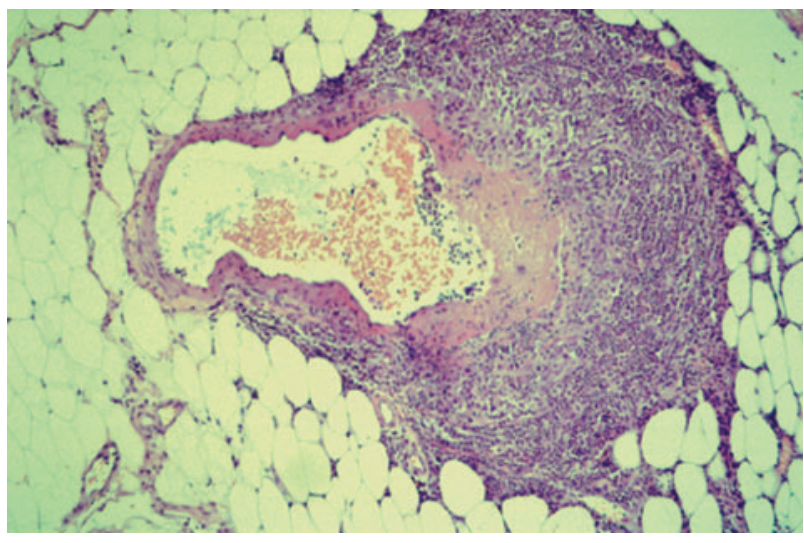

Figure 2 Biopsy of the greater omentum: focal necrotising vasculitis of the venules.

\section{DISCUSSION}

To our knowledge this is the first case which describes severe, biopsy verified involvement of the omentum, complicated by massive intra-abdominal bleeding in a patient with Wegener's granulomatosis. Severe gastrointestinal involvement in Wegener's granulomatosis has been reported occasionally, ${ }^{1-3}$ although abdominal involvement may be detected in a significant number of patients at necropsy. ${ }^{4}$ The main complications include intestinal perforation, ulceration, ischaemia, and haemorrhage in both the small and large intestine. ${ }^{1}$ As in the case presented here, gastrointestinal disease occurred shortly after diagnosis and the start of immunosuppressive treatment in these previous reports. ${ }^{12}$ A relationship between this therapeutic strategy in active disease and the occurrence of intestinal necrosis and perforation of the intestinal tract, or involvement of the omentum in our case, however, seems to be unlikely. The long term improvement of the disease without further severe intestinal disease seen in our patient, who was treated with cyclophosphamide for over 18 months after occurrence of severe intra-abdominal bleeding, does not support such a relationship.

Another point to be made concerns the need for surgery. Our case clearly shows that intra-abdominal bleeding requiring immediate surgical intervention may complicate Wegener's granulomatosis. Therefore diagnosing haemorrhage is important as other causes of acute abdominal pain-for example, splenic rupture or abscess, perforation of a hollow viscous or ruptured aortic aneurysm, may also need emergency laparotomy. ${ }^{5}$ As stated before, this may happen early in the course of the disease or even at onset of the disease, especially in patients with existing severe renal and pulmonary involvement. ${ }^{15}$ Although rare, severe necrotising vasculitis of the omentum should be considered in the differential diagnosis of acute abdominal pain in patients with rapidly proceeding Wegener's granulomatosis. 


\section{Authors' affiliations}

E J A Kroot, C L P Mak, M P C Middelkoop, A Dees, Department of Internal Medicine, Ikazia Hospital, Rotterdam, The Netherlands R U Boelhouwer, Department of Surgery, Ikazia Hospital, Rotterdam, The Netherlands

\section{REFERENCES}

1 Storesund B, Gran JT, Koldingsnes W. Severe intestinal involvement in Wegener's granulomatosis: report of two cases and review of the literature. Br J Rheumatol 1998:37:387-90.

2 Lie JT. Wegener's granulomatosis: histological documentation of common and uncommon manifestations in 216 patients. Vasa 1997;26:261-70.

3 Jenette JC, Falk RJ. Small-vessel vasculitis. N Engl J Med 1997;337:1512-23.

4 Walton EW. Giant cell granuloma of the respiratory tract (Wegener's Granulomatosis). BMJ 1958;ii:265-70.

Correspondence to: Dr E J A Kroot, Ikazia Hospital, Montessoriweg 1, 3083 AN Rotterdam, The Netherlands; ejankroot@yahoo.com
5 Roy DK, George A, Chattopadhyay C, Grennan DM. Splenic infarction in a patient with Wegener's granulomatosis. Rheumatology (Oxford) 1999;38:1162-3.

\section{Infliximab in refractory spondyloarthropathies: a multicentre 38 week open study}

\section{E Collantes-Estévez, M C Muñoz-Villanueva, J D Cañete-Crespillo, R Sanmarti-Sala, J Gratacós- Masmitjá, P Zarco-Montejo, J C Torre-Alonso, C González-Fernández}

$\mathrm{S}$ patients (20-30\%) with spondyloarthropathies (SpA) have a persistent and disabling disease, ${ }^{1}$ for which a limited number of alternative therapeutic approaches exist. ${ }^{2}$ The successful results from randomised, double blind, placebo controlled trials in ankylosing spondylitis (AS) and SpA which have been published ${ }^{3-5}$ suggest that treatment with infliximab is highly effective. However, in most of these studies, criteria for the selection of patients are based on active disease, but not on refractory disease (failure of response to previous drugs, including non-steroidal antiinflammatory drugs (NSAIDs) and disease modifying antirheumatic drugs). Therefore, we aimed at assessing the effectiveness and safety of infliximab in patients with active and refractory SpA.

\section{PATIENTS AND METHODS}

The study was an open label, multicentre, 38 week prospective study in 40 patients with active and refractory
SpA: 34 patients had AS, 3 had arthritis with related inflammatory bowel disease, and 3 undifferentiated SpA. Infliximab (5 mg/kg) was given at weeks $0,2,6,14,22$, and 30. Patients were included according to the criteria of the European Spondyloarthropathy Study Group and/or Amor's criteria for SpA. At the time of inclusion, all patients had active and refractory disease, defined as no satisfactory response to full doses of at least three different NSAIDs $^{6}$ and/or no response to sulfazalazine in a minimum daily dose of $2 \mathrm{~g}$ for at least three months or to methotrexate at a minimum dose of $15 \mathrm{mg} /$ week for at least two months.

Clinical evaluations were carried out at all visits (before the infusion) and at week 38. We evaluated: the Bath Ankylosing Spondylitis Disease Activity Index (BASDAI), the Bath Ankylosing Spondylitis Functional Index (BASFI), patient global assessment of disease status, patient pain assessment, inflammation (represented by the mean of the two morning

Table 1 Assessments* of patients $(n=40)$

\begin{tabular}{|c|c|c|c|c|}
\hline & Baseline & Week 14 & Week 38† & $\begin{array}{l}\text { Mean } \\
\text { change \% } \\
\text { (0-38 weeks) }\end{array}$ \\
\hline BASDAI, 0-100 mm VAS & $71(14)$ & $34(23) \S$ & $37(23) \S$ & 48 \\
\hline BASFI, 0-100 mm VAS & $69(16)$ & $41(24) \S$ & $47(27) \S$ & 32 \\
\hline Patient global assessment, 0-100 mm VAS & 79 (13) & $44(26) \S$ & $46(29) \S$ & 42 \\
\hline Patient pain assessment, 0-100 mm VAS & $86(11)$ & $46(29) \S$ & $50(32) \S$ & 42 \\
\hline Inflammation $\ddagger, 0-100 \mathrm{~mm}$ VAS & $77(22)$ & $32(26) \S$ & $36(27) \S$ & 53 \\
\hline SF-36: PCS and MCS & 24 and 45 & & 48 and $63 \S$ & 100 and 40 \\
\hline $\mathrm{ESR}, \mathrm{mm} / 1^{\text {st }} \mathrm{h}$ & $35(26)$ & $14(17) \S$ & $22(23) \S$ & 37 \\
\hline $\mathrm{CRP}, \mathrm{mg} / \mathrm{l}$ & $30.4(31.9)$ & $10.6(18.1) \S$ & $14.4(16.6) \S$ & 53 \\
\hline \multicolumn{5}{|l|}{ Metrological variables: } \\
\hline Chest expansion, $\mathrm{cm}$ & $2.5(1.2)$ & - & $3.2(1.3) \S$ & 28 \\
\hline Modified Schober, cm & $3.7(2.8)$ & - & $4.5(3.5) \S$ & 22 \\
\hline Occiput to wall, $\mathrm{cm}$ & $5.5(6.5)$ & - & $4.6(5.9)$ & 16 \\
\hline Fingers to floor distance, $\mathrm{cm}$ & $27.9(14.0)$ & - & $24.5(12.2) \S$ & 12 \\
\hline
\end{tabular}

VAS, visual analogue scale; BASDAI, Bath Ankylosing Spondylitis Disease Activity Index; BASFI, Bath Ankylosing Spondylitis Functional Index; ESR, erythrocyte sedimentation rate; CRP, C reactive protein; SF-36, Short Form-36 items; PCS, physical component score; MCS, mental component score.

*Values are means (SD); †to include the three patients who withdrew, the last observation carried forward method was applied; tinflammation is represented by the mean of the two morning stiffness related BASDAI VAS scores (intensity and duration). Significance of the change from baselines was measured by analysis of variance of repeated measures, and the post hoc multiple comparison tests were performed for Bonferroni's test. Statistical significance of metrological variables and SF-36 domains was determined by paired samples Student's $t$ test with Bonferroni's correction; §significant differences versus baseline, $\mathrm{p}<0.05$ 

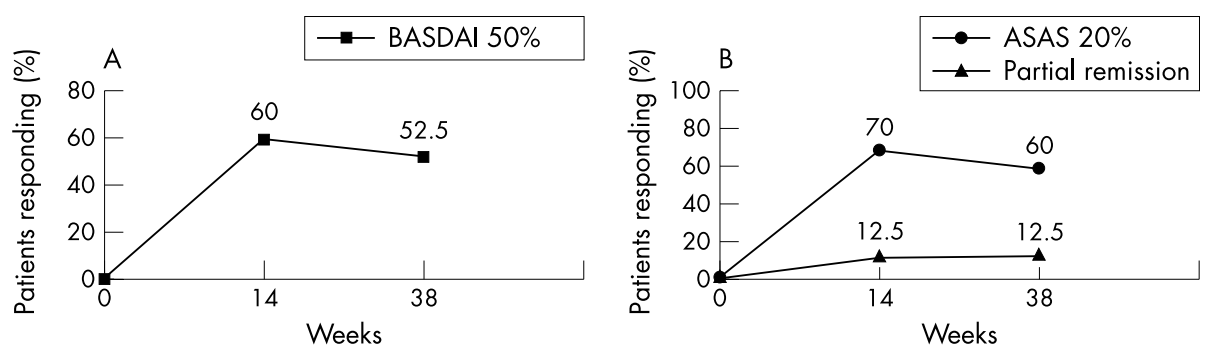

Figure 1 Measured by the Bath Ankylosing Spondylitis Disease Activity Index on the 50\% improvement level (BASDAl; fig 1A) and by criteria of ankylosing spondylitis working group for $20 \%$ improvement and partial remission (ASAS; fig 1B). No significant differences were detected between weeks 14 and 38 by the McNemar test.

stiffness related BASDAI visual analogue scale scores), health related assessment of quality of life using the short form (SF-36) method, ${ }^{7}$ chest expansion, modified Schober, fingers to floor and occiput to wall tests. The primary outcomes variables were $50 \%$ improvement of disease activity (BASDAI 50\%) between baseline and weeks 14 (after three infusions) and 38 (after six infusions). All our patients had axial involvement (alone or associated with the peripheral form), so we also used end points proposed by the Assessments in AS (ASAS) Working Group. ${ }^{8}$ Latent tuberculosis infection was investigated in all patients before study entry by a tuberculin test and chest radiographs.

\section{RESULTS AND DISCUSSION}

Thirty two men and eight women (mean age 41 years and mean disease duration 16 years) were studied. Eighteen patients had axial disease alone and 22 had axial and peripheral disease (mixed form). Table 1 shows the results of the variables evaluated at each visit. A significant and rapid improvement (after the first evaluation) was seen in all the variables analysed, except for occiput to wall test, and remained until week 38 (table 1). Increased values were seen in SF-36 measures that reached statistical significance in all domains $(p<0.001)$.

A reduction in BASDAI of $50 \%$ or more compared with baseline was achieved in 24 patients $(60 \%$; 95\% confidence interval (CI) $43 \%$ to $75 \%$ ) at week 14 and in 21 patients (52.5\%; $95 \%$ CI $36 \%$ to $68 \%$ ) at week 38 (fig 1A). When response to treatment was analysed according to ASAS criteria (fig 1B): a $20 \%$ improvement was observed in 28 patients $(70 \% ; 95 \%$ CI $53 \%$ to $83 \%$ ) at week 14 and in 24 patients $(60 \%$; $95 \%$ CI $25 \%$ to $57 \%)$ at week $38 ; 5$ patients (12.5\%; $95 \%$ CI $4 \%$ to $27 \%$ ) achieved partial remission at weeks 14 and 38. Improvement was similar in the patients with axial disease alone and in those with mixed forms.

Five adverse events were reported during the study: two patients had increased transaminase serum levels (one of them with persistently high levels was withdrawn from the study); one patient had an infectious prostatitis (re-entered into the study after antibiotic treatment and recovery); one transient anaphylactoid reaction (withdrawn), and another had a chorioretinitis (withdrawn). Thirty seven patients completed the 38 week follow up.

In conclusion, the results of this open prospective trial clearly indicate that infliximab is an effective therapeutic option for patients with refractory SpA.

\section{ACKNOWLEDGEMENTS}

We are indebted to Schering-Plough (Spain) and Centocor for the supply of the drug. We thank Dr Elisa Muñoz for statistical assistance.

\section{Authors' affiliations}

E Collantes-Estévez, Rheumatology Service, Reina Sofia University Hospital of Córdoba, Spain

M C Muñoz-Villanueva, Research Unit, Reina Sofia University Hospital of Córdoba, Spain

J D Cañete-Crespillo, R Sanmartí-Sala, Rheumatology Service, Clinic Hospital of Barcelona, Spain

J Gratacós-Masmitiá, Rheumatology Service, Parc Taulí Hospital of Sabadell, Spain

P Zarco-Montejo, Rheumatology Service, Alcorcon Foundation Hospital of Madrid, Spain

J C Torre-Alonso, Rheumatology Service, Monte Naranco Hospital of Oviedo, Spain

C González-Fernández, Rheumatology Service, Gregorio Marañón Hospital of Madrid, Spain

The authors are members of the Spanish Spondyloarthropathy Study Group

Correspondence to: Professor E Collantes-Estévez. Servicio de Reumatología, Hospital Universitario Reina Sofía. Avda Menéndez Pidal s/n, Córdoba-14011, Spain;

eduardo.collantes.sspa@juntadeandalucia.es

Accepted 15 March 2003

\section{REFERENCES}

1 Zink A, Braun J, Listing J, Wollenhaupt J. Disability and handicap in rheumatoid arthritis and ankylosing spondylitis-results from the German rheumatological database collaborative arthritis centres. I Rheumatol 2000;27:613-22

2 Dougados M. Disease controlling antirheumatic therapy in spondyloarthropathy. J Rheumatol 2001;28(suppl 62):16-20.

3 Braun J, Brandt J, Listing J, Zink A, Alten R, Golder W, et al. Treatment of active ankylosing spondylitis with infliximab: a randomised controlled multicentre trial. Lancet 2002;359:1 187-93.

4 Van den Bosch F, Kruithof E, Baeten D, Herssens A, Keyser F, Mielants H, et al. Randomized double-blind comparison of chimeric monoclonal antibody to tumour necrosis factor $\alpha$ (infliximab) versus placebo in active spondyloarthropathy. Arthritis Rheum 2002;46:755-65.

5 Braun J, Sieper J, Breban M, Collantes-Estevez E, Davis J, Inman R, et al. Antitumour necrosis factor alpha therapy for ankylosing spondylitis: international experience. Ann Rheum Dis 2002;61(suppl III):iii51-60.

6 Amor B, Dougados M, Khan MA. Management of refractory ankylosing spondylitis and related spondyloarthropathies. Rheum Dis Clin North Am 1995; 1:117-28

7 Ware JE Jr, Sherbourne CD. The MOS 36-item short-form health survey (SF 36). Conceptual framework and item selection. Med Care 1992;30:473-83.

8 Anderson JJ, Baron G, Van der Heijde D, Felson DT, Dougados M. Ankylosing Spondylitis Assessment Group preliminary definition of short-term improvement in ankylosing spondylitis. Arthritis Rheum 2001; 44:1876-86. 


\title{
High incidence of hepatotoxicity of isoniazid treatment for tuberculosis chemoprophylaxis in patients with rheumatoid arthritis treated with methotrexate or sulfasalazine and anti- tumour necrosis factor inhibitors
}

\author{
J Vanhoof, S Landewe, E Van Wijngaerden, P Geusens
}

Ann Rheum Dis 2003;62:1241-1242. doi: 10.1136/ard.2002.004598

$\mathrm{T}$ umour necrosis factor (TNF) inhibition is a major breakthrough in the treatment of rheumatoid arthritis (RA). Infliximab, etanercept, and adalimumab are available TNF inhibitors that have been used and investigated extensively in RA. ${ }^{1-3}$ Reactivation of latent tuberculosis (TB) during anti-TNF treatment has been reported and therefore recommendations are made to screen patients for latent $\mathrm{TB}$ before starting TNF blocking agents. ${ }^{4}$

However, treatment with isoniazid (INH) can result in severe adverse effects. The two most important untoward effects of INH treatment are hepatitis and peripheral neuropathy. Peripheral neuritis associated with INH treatment can be reduced by the prophylactic administration of vitamin B6 (pyridoxine) $250 \mathrm{mg} /$ week. INH associated hepatotoxicity can be severe and life threatening, with a death rate of $10 \% .^{5}$ Age seems to be the most important factor in determining the risk of important liver injury. Also a contributory role of alcohol consumption has been noted. The characteristic pathological process is bridging and multilobular necrosis. The severity of damage tends to increase if the drug is continued after symptoms of hepatic dysfunction have appeared. A reactive metabolite of acetylhydrazine, a metabolite of INH, may be responsible for liver injury, and patients who are rapid acetylators would be prone to such injury.

During the past year, the Biomedical Research Institute participated in several double blind randomised clinical trials to evaluate the effect and safety of treatment with TNF inhibitors in RA with methotrexate or sulfasalazine as the concomitant disease modifying drug (DMARD) treatment in 88 patients (table 1 ). Of these patients, 11 had a positive purified protein derivative (PPD) skin test (skin induration more than $5 \mathrm{~mm}$ ) and two other patients had chest $x$ ray abnormalities, possibly suggesting latent TB. In eight patients prophylactic treatment with INH $300 \mathrm{mg} /$ day (+ pyridoxine $250 \mathrm{mg}$ /week) was started. The other five patients were not given INH as the trial was ended for various reasons, shortly after performing the PPD skin test and chest $x$ ray; one patient refused INH treatment. In four of eight patients treated with INH (and pyridoxine) at standard doses mild to severe hepatic dysfunction was noted. In three of these four patients discontinuation of INH resulted in a normalisation of the transaminase activity. The incidence of liver dysfunction in our patients considerably exceeds the reported incidence of hepatotoxicity of INH treatment. ${ }^{5-7}$ Interference with DMARD treatment, such as methotrexate and sulfasalazine, is probably the major reason for hepatotoxicity. In one patient excessive alcohol consumption might have had a contributory role, but it has to be noted that in this patient liver dysfunction was not seen before starting INH treatment. These results already justify a higher awareness of this adverse effect during treatment with tuberculosis chemoprophylaxis in patients with RA treated with sulfasalazine or methotrexate with or without anti-TNF treatment.

The American Thoracic Society recommends that serum concentrations of aspartate aminotransferase and alanine aminotransferase are determined at baseline in patients over 35 years of age who are receiving INH for chemoprophylaxis, with monthly determinations thereafter. What to recommend if INH has to be stopped remains unclear; a rifampin plus pyrazinamide combination cannot be recommended because its hepatotoxicity rate is even higher than for INH

Table 1 Characteristics of the total patient group and of patients developing liver dysfunction

\begin{tabular}{|c|c|c|c|c|c|c|c|c|c|}
\hline Trial drug & $\begin{array}{l}\text { Enrolled } \\
\text { patients } \\
\text { (n) }\end{array}$ & $\begin{array}{l}\text { Positive } \\
\text { PPD skin } \\
\text { test }\end{array}$ & $\begin{array}{l}\text { Signs of } \\
\text { latent TB on } \\
\text { chest } x \text { ray }\end{array}$ & $\begin{array}{l}\text { Patients } \\
\text { treated with } \\
\text { INH (n) }\end{array}$ & $\begin{array}{l}\text { Patients with } \\
\text { liver } \\
\text { dysfunction } \\
\text { (n) }\end{array}$ & $\begin{array}{l}\text { Age (years) and } \\
\text { sex of patients } \\
\text { with liver } \\
\text { dysfunction }\end{array}$ & $\begin{array}{l}\text { AST (ULN 45), } \\
\text { ALT (ULN 46) } \\
\text { (IU/I) }\end{array}$ & $\begin{array}{l}\text { Weeks of } \\
\text { exposure to INH } \\
\text { before liver } \\
\text { dysfunction (n) }\end{array}$ & $\begin{array}{l}\text { Weeks before } \\
\text { recovery after } \\
\text { discontinuation } \\
\text { of INH }(n)\end{array}$ \\
\hline $\begin{array}{l}\text { MTX + infliximab } \\
\text { (or placebo) }\end{array}$ & 54 & 8 & 1 & 5 & 2 & $48-$ male & 50,82 & 14 & $\begin{array}{l}8 \text { (dose } \\
\text { reduction MTX) }\end{array}$ \\
\hline $\begin{array}{l}\text { MTX + etanercept } \\
\text { (or placebo) }\end{array}$ & 4 & 0 & 0 & 0 & 0 & $\begin{array}{l}53-\text { male } \\
-\end{array}$ & $\begin{array}{l}304,120 \\
-\end{array}$ & $\begin{array}{l}7 \\
-\end{array}$ & $\begin{array}{l}4 \\
-\end{array}$ \\
\hline $\begin{array}{l}\text { SSZ + etanercept } \\
\text { (or placebo) }\end{array}$ & 22 & 3 & 0 & 3 & 2 & 71 - female & 188,330 & 16 & 4 \\
\hline $\begin{array}{l}\text { MTX + adalimumab } \\
\text { (or placebo) }\end{array}$ & 8 & 0 & 1 & 0 & 0 & $\begin{array}{l}55-\text { male } \\
-\end{array}$ & $\begin{array}{l}103,197 \\
-\end{array}$ & $\begin{array}{l}8 \\
-\end{array}$ & $\begin{array}{l}11 \\
-\end{array}$ \\
\hline Total & 88 & 11 & 2 & 8 & 4 & - & - & - & - \\
\hline
\end{tabular}

PPD, purified protein derivative; TB, tuberculosis; INH, isoniazid; AST, aspartate aminotransferase; ALT, alanine aminotransferase; MTX, methotrexate; SSZ, sulfasalazine; ULN, upper limit of normal. 
treatment. A possible solution may be rifampin alone for four months after resolution of INH hepatotoxicity. ${ }^{5}{ }^{7}$

Since the anti-TNF era, rheumatologists should take special care with the use and monitoring of long term INH treatment in combination with potentially hepatotoxic drugs such as sulfasalazine and methotrexate. Further studies and reports of monitoring and observation of hepatotoxicity of INH treatment in RA patients concomitantly treated with DMARDs during anti-TNF treatment are mandatory. ${ }^{8}$

\section{Authors' affiliations}

J Vanhoof, S Landewe, Clinical Research Centre for Bone and Joint Diseases, Biomedical Research Institute, Limburg University Centre, Diepenbeek, Belgium

E Van Wijngaerden, Department of Internal Medicine/Infectious Diseases, University Hospitals Leuven, Leuven, Belgium

P Geusens, Department of Rheumatology, Academisch Ziekenhuis, Maastricht, The Netherlands

Correspondence to: Dr P Geusens, Biomedical Research Institute, Limburgs Universitair Centrum, 3590, Diepenbeek, Belgium; piet.geusens@ping.be

Accepted 29 June 2003

\section{REFERENCES}

1 Moreland LW, Baumgartner SW, Schiff MH, Tindall EA, Fleischmann RM, Weaver AL, et al. Treatment of rheumatoid arthritis with a recombinant human tumor necrosis factor receptor (p75)-Fc fusion protein. N Engl J Med 1997:337:141-7.

2 Maini R, St Clair EW, Breedveld F, Furst D, Kalden J, Weisman M, et al. Infliximab (chimeric anti-tumour necrosis factor alpha monoclonal antibody) versus placebo in rheumatoid arthritis patients receiving concomitant methotrexate: a randomised phase III trial. ATRRACT Study Group. Lancet 1999:354:1932-9.

3 Wollheim FA. TNF inhibition as treatment for rheumatoid arthritis. Expert Opin Investig Drugs 2002;11:947-53.

4 Keane J, Gershon S, Wise RP, Mirabile-Levens E, Kasznica J, Schwieterman WD, et al. Tuberculosis associated with infliximab, a tumor necrosis factor alpha-neutralizing agent. N Engl J Med 2001;345:1098-104.

5 Dienstag JL, Isselbacher KJ. Toxic and drug-induced hepatitis. In: Isselbacher KJ, Braunwald E, Wilson JD, Martin JB, Fauci AS, Kasper DL, eds. Harrison's principles of internal medicine, 14th ed. New York: McGraw-Hill, 1998:1692-6.

6 Wright PW, Wallace RJ. Antimycobacterial agents. In: Isselbacher KJ, Braunwald E, Wilson JD, Martin JB, Fauci AS, Kasper DL, eds. Harrison's Principles of Internal Medicine, 14th ed. New York: McGraw-Hill, 1998:997-1003.

7 American Thoracic Society/Centers for Disease Control and Prevention/ Infectious Diseases Society of America. Treatment of tuberculosis. Am J Respir Crit Care Med 2003; 167:603-62.

8 Hernandez-Cruz B, Ponce-de-Leon-Rosales S, Sifuentes-Osornio J, Ponce-deLeon-Garduno A, Diaz-Jouanen E. Tuberculosis prophylaxis in patients with steroid treatment and systemic rheumatic diseases. A case-control study. Clin Exp Rheumatol 1999;17:81-7.

\title{
Insurance problems among patients with ankylosing spondylitis
}

\author{
A Boonen, A van Tubergen, Si van der Linden
}

$\mathrm{n}$ a retrospective questionnaire survey, 129 Dutch patients with ankylosing spondylitis (AS) were asked if they had had difficulties in arranging a medical insurance, an additional work disability insurance, or a life assurance. Patients who had arranged the insurance after diagnosis were compared with those who had arranged the insurance before diagnosis. A restraint in arranging the insurance was defined as ( $a$ ) a higher premium; $(b)$ exclusion for AS related problems. Ninety four $(73 \%)$ patients were male, with a mean (SD) age of 49 (10) years, mean (SD) disease duration

Table 1 Comparison of restraints imposed in the insurance contract to 129 patients with ankylosing spondylitis who arranged the insurance before, as opposed to after, diagnosis of disease

\begin{tabular}{llll}
\hline & $\begin{array}{l}\text { Contract } \\
\text { before } \\
\text { diagnosis }\end{array}$ & $\begin{array}{l}\text { Contract } \\
\text { after } \\
\text { diagnosis }\end{array}$ & \\
\cline { 2 - 2 } & No $(\%)$ & No $(\%)$ & p Value \\
\hline $\begin{array}{c}\text { Medical insurance } \\
\text { Patients } \\
\text { Restraints }\end{array}$ & 114 & 15 & \\
$\begin{array}{c}\text { Work disability insurance } \\
\text { Patients } \\
\text { Restraints }\end{array}$ & $0(0)$ & $2(13)$ & 0.005 \\
$\begin{array}{c}\text { Life assurance } \\
\text { Patients } \\
\text { Restraints }\end{array}$ & $0(0)$ & $2(11)$ & 0.47 \\
\hline
\end{tabular}

of 12 (10) years, and mean (SD) educational level of 13 (4) years. One hundred and three $(80 \%)$ were married, age and sex adjusted employment was $57 \%$ and age and sex adjusted work disability was $33 \%$. Table 1 compares the number of patients who had arranged the insurance before or after diagnosis, and within each group the proportion of patients for whom restrictions in the contract were imposed.

Despite the small number of patients in this survey, it is clear that in the Netherlands, at least for medical insurance and life assurance, a substantial number of patients with AS encounter problems. This is especially relevant because AS is increasingly diagnosed at younger age. Because there is evidence that health resource use and work disability are especially increased in patients with more severe disease $\mathrm{e}^{1-4}$ and because it has been shown that mortality is only increased in patients with longstanding or complicated disease, ${ }^{5-8}$ the course of disease severity should be taken into account when performing insurance risk assessments. It should be discussed how these considerations might be implemented in practice.

\section{Authors' affiliations}

A Boonen, A van Tubergen, Si van der Linden, Department of Internal Medicine, Division of Rheumatology, University Hospital Maastricht, The Netherlands

Correspondence to: $\operatorname{Dr}$ A Boonen, Department of Internal Medicine, Division of Rheumatology, University Hospital Maastricht, PO Box 5800, 6202 AZ Maastricht, The Netherlands; aboo@sint.azm.nl 


\section{REFERENCES}

1 Boonen A, van der Heijde D, Landewé R, Spoorenberg A, Schouten H, Rutten van Molken $M$, et al. Work status and productivity costs due to ankylosing spondylitis: comparison of three European countries. Ann Rheum Dis 2002:61:429-37.

2 Boonen A, van der Heijde D, Landewé R, Guillemin F, Rutten van Mölken $M$, Dougados $M$, et al. Direct costs of ankylosing spondylitis and its determinants. An analysis among three European countries. Ann Rheum Dis 2003:62:732-40.

3 Ward MM. Functional disability predicts total costs in patients with ankylosing spondylitis. Arthritis Rheum 2002;46:223-31.
4 Ward M, Kuzis S. Risk factors for work disability in patients with ankylosing spndylitis. J Rheumatology (Oxford) 2001;28:315-21.

5 Carbone LD, Cooper C, Michet CJ, Atkinson EJ, O'Fallon WM, Melton U, 3rd. Ankylosing spondylitis in Rochester, Minnesota, 1935-1989. Is the epidemiology changing? Arthritis Rheum 1992;35:1476-82.

6 Carter ET, McKenna CH, Brian DD, Kurland LT. Epidemiology of ankylosing spondylitis in Rochester, Minnesota, 1935-1973. Arthritis Rheum 1979:22:365-70.

7 Khan MA, Khan MK, Kushner I. Survival among patients with ankylosing spondylitis: a life-table analysis. J Rheumatol 1981;8:86-90.

8 Lehtinen K. Mortality and causes of death in 398 patients admitted to hospital with ankylosing spondylitis. Ann Rheum Dis 1993;52:174-6.

\title{
Anti-tumour necrosis factor $\alpha$ treatment in chronic recurrent inflammation of the anterior segment of the eye in patients resistant to standard immunomodulatory treatment
}

\author{
Y El-Shabrawi, H Mangge, J Hermann
}

Ann Rheum Dis 2003;62:1243-1244. doi: 10.1136/ard.2003.008615

$\mathrm{R}$ ecurrent or chronic anterior uveitis leads to a drop of vision below $20 / 50$ in $23 \%$ of patients; $11 \%$ will eventually be legally blind. ${ }^{12}$ Thus the treatment of these patients still presents a challenge, and additional treatments are needed. In a previous study we found that anti-tumour necrosis factor $\alpha$ (anti-TNF $\alpha$ ) treatment was highly efficient in a patient with an acute HLA-B27 associated uveitis. ${ }^{3}$ Thus we tested the efficacy of anti-TNF $\alpha$ treatment, consisting of a combined immunomodulatory drug and corticosteroids, in chronic inflammatory diseases of the anterior segment of the eye, non-responsive to standard anti-inflammatory treatment.

\section{PATIENTS}

Nine patients with uveitis with associated systemic disease were included (table 1). Eight of these patients had a rheumatic disease (five had a spondyloarthropathy (all were HLA-B27 positive), two had juvenile idiopathic arthritis (JIA; one Still's disease, one antinuclear antibody (ANA) positive oligoarthritis)) and one patient had a necrotising sclerouveitis associated with Wegener's granulomatosis. One patient with uveitis with an associated tubulointerstitial nephritis (TINU) was also included. Disease modifying antirheumatic drug (DMARD) treatment was started at least three months before infliximab treatment. It consisted of methotrexate (MTX) in seven patients, of whom two received a combination of MTX and mycophenolate-mofetil. One patient received cyclophosphamide, and one leflunomide. Because the response was inadequate towards even combined immunosuppressant treatment (for example, MTX plus mycophenolate-mofetil) or because of the massive destructive activity of the disease (for example, necrotising sclerouveitis) a quick acting active anti-inflammatory substance was needed. Because a quick response towards infliximab had been seen in a previous study, it was chosen again. ${ }^{3}$

\section{RESULTS}

Recurrent or chronic uveitis despite immunomodulatory treatment was present for a mean (SD) period of 8.6

Table 1 Clinical data and follow up in the patients treated. The visual acuity of the inflamed eye (right eye (od), left eye (os) or if both eyes had the same VA ou are listed)

\begin{tabular}{|c|c|c|c|c|c|c|c|c|c|}
\hline $\begin{array}{l}\text { Infusions } \\
\text { at week }\end{array}$ & $\begin{array}{l}\text { Re-treatment } \\
\text { at week }\end{array}$ & Treatment at baseline & $\begin{array}{l}\text { Treatment after } \\
\text { infliximab }\end{array}$ & Diagnosis & $\begin{array}{l}\text { VA at } \\
\text { baseline }\end{array}$ & $\begin{array}{l}\text { VA after } \\
\text { treatment }\end{array}$ & $\begin{array}{l}\text { Follow up } \\
\text { (weeks) }\end{array}$ & $\begin{array}{l}\text { Duration of } \\
\text { flare (days) }\end{array}$ & $\begin{array}{l}\text { Flare up } \\
\text { (month) }\end{array}$ \\
\hline 0 & None & $\begin{array}{l}32.5 \mathrm{mg} / \text { day } \\
\text { prednisone+20 mg MTX }\end{array}$ & $15 \mathrm{mg}$ MTX & HLA-B27 & $20 / 100$ & $20 / 30$ & 70 & 7 & 5 \\
\hline $0 / 2 / 6$ & $26 / 28 / 32$ & $12.5 \mathrm{mg}$ MTX & $12.5 \mathrm{mg}$ MTX & HLA-B27 & $20 / 40$ & $15 / 20$ & 82 & 2 & 6 \\
\hline $0 / 2 / 6$ & None & $\begin{array}{l}17.5 \mathrm{mg} / \text { day prednisone } \\
+15 \mathrm{mg} \text { MTX }\end{array}$ & $12.5 \mathrm{mg}$ MTX & HLA-B27 & $20 / 25$ & $15 / 20$ & 78 & 5 & 5 \\
\hline $0 / 2 / 6$ & None & $\begin{array}{l}20 \mathrm{mg} \mathrm{MTX}+2 \mathrm{~g} \\
\text { CellCept+steroid drops }\end{array}$ & $\begin{array}{l}20 \mathrm{mg} \mathrm{MTX}+2 \mathrm{~g} \\
\text { CellCept }\end{array}$ & HLA-B27 & $20 / 125$ & $20 / 60$ & 8 & 42 & - \\
\hline $0 / 2 / 6$ & None & $17.5 \mathrm{mg}$ MTX & 15 mg MTX & HLA-B27 & $20 / 20$ & $20 / 20$ & 48 & 7 & 6 \\
\hline $0 / 2 / 6$ & $\begin{array}{l}18 / 22 / \\
28 / 33\end{array}$ & $\begin{array}{l}10 \mathrm{mg} \mathrm{MTX}+2 \mathrm{~g} \\
\text { CellCept+steroid drops }\end{array}$ & $12.5 \mathrm{mg} \mathrm{MTX}$ & JIA & $20 / 25$ ou & $20 / 25$ ou & 36 & 35 & 1 \\
\hline $0 / 2 / 6$ & $\begin{array}{l}10 / 14 / \\
18 / 22 / 26\end{array}$ & Leflunomide & Leflunomide & $J \mathrm{~A}$ & $20 / 200$ & $20 / 80$ & 30 & 42 & 4 \\
\hline $0 / 2 / 6$ & $20 / 28$ & $\begin{array}{l}\text { Cyclophosphamide } \\
\text { +prednisone } 25 \mathrm{mg} / \text { day }\end{array}$ & $\begin{array}{l}\text { Prednisone } \\
12.5 \mathrm{mg} / \text { day }\end{array}$ & Scleritis & $\begin{array}{l}20 / 200 \text { od, } \\
\text { CF os }\end{array}$ & $\begin{array}{l}20 / 60 \text { od, } \\
\text { CF os }\end{array}$ & 30 & 90 & - \\
\hline $0 / 2 / 6$ & 10 & $\begin{array}{l}10 \mathrm{mg} / \text { day prednisone } \\
+15 \mathrm{mg} \mathrm{MTX}\end{array}$ & $\begin{array}{l}10 \mathrm{mg} / \text { day } \\
\text { Prednisone+15 mg } \\
\text { MTX }\end{array}$ & TINU & $\begin{array}{l}20 / 200 \text { od, } \\
\text { CF os }\end{array}$ & $\begin{array}{l}20 / 200 \text { od, } \\
\text { CF os }\end{array}$ & 22 & * & \\
\hline
\end{tabular}

*In the patient with TINU syndrome no remission was achieved. 
(4.1) months before infliximab treatment. Infliximab was given at a dose of $3 \mathrm{mg} / \mathrm{kg}$ body weight at weeks 0,2 , and 6 in all but one patient who received only one infusion owing to a reaction after her first infusion. After anti-TNF $\alpha$ treatment the mean (SD) duration of the uveitis was 12.6 (11.7) days in HLA-B27 positive patients with uveitis and 38.5 (3.5) days in patients with JIA. In the patient with Wegener's granulomatosis the time to remission was three months. The infliximab treatment had no effect in the patient with TINU. Patients with HLA-B27 associated uveitis remained in remission for an average of 5.5 (0.5) months. This 5.5 months' duration of response was similarly achieved after re-treatment of these patients. In the patients with JIA the anti-inflammatory effect of TNF $\alpha$ blockage was much more moderate and only transient. In the patients with oligoarthritis the remission of uveitis after three infliximab infusions lasted for five weeks only and as seen in the patient with Still's disease the uveitis became active again despite increasing the dose of infliximab after about 30 weeks. Thus it seems, as seen in the patient with Still's disease, that the effect of TNF $\alpha$ treatment is reduced to some extent over the long term.

\section{DISCUSSION}

HLA-B27 associated uveitis as well as the sclero-uveitis in the patient with Wegener's granulomatosis responded well to infliximab treatment. In all these patients a sustained antiinflammatory effect was achieved. This is in accordance with the previously described positive effect of anti-TNF $\alpha$ treatment on the systemic manifestations of the spondyloarthropathies $^{45}$ and Wegener's granulomatosis. ${ }^{6}$ However, in both patients with chronic uveitis in association with JIA, the antiinflammatory effect of infliximab on the eyes was not sustained. The overall moderate response towards $\mathrm{TNF} \alpha$ blockade that we found in our patients with JIA is comparable with the results of a previous report. ${ }^{7}$ We are aware that only isolated cases are presented, but together the results of our study suggest that anti-TNF $\alpha$ treatment is not equally applicable to all forms of anterior uveitis but that ocular inflammations associated with the spondyloarthropathies, especially, are highly responsive to anti-TNFo treatment. Prospective, "blinded" studies will be required to examine these differences further.

\section{Authors' affiliations}

Y El-Shabrawi, Department of Ophthalmology, Karl-Franzens University, Graz, Austria

H Mangge, Department of Laboratory Medicine and Paediatric Immunology/Rheumatology, Karl-Franzens University, Graz, Austria

J Hermann, Department of Internal Medicine, Karl-Franzens University, Graz, Austria

Correspondence to: Dr Y El-Shabrawi, Department of Ophthalmology, Karl Franzens University Hospital, Avenbruggerplatz 4, 8036 Graz, Austria; yosuf.elshabrawi@kfunigraz.ac.at

Accepted 4 August 2003

\section{REFERENCES}

1 Rothova A, Suttorp-van Schulten MS, Frits Treffers W, Kijlstra A. Causes and frequency of blindness in patients with intraocular inflammatory disease. $\mathrm{Br} J$ Ophthalmol 1996;80:332-6.

2 Power WJ, Rodriguez A, Pedroza-Seres M, Foster CS. Outcomes in anterior uveitis associated with the HLA-B27 haplotype. Ophthalmology 1998; 105:1646-51.

3 El-Shabrawi Y, Hermann J. Anti-tumor necrosis factor-alpha therapy with infliximab as an alternative to corticosteroids in the treatment of human leukocyte antigen B27-associated acute anterior uveitis. Ophthalmology 2002; 109:2342-6.

4 Braun J, Sieper J, Breban M, Collantes-Estevez E, Davis J, Inman R, et al. Antitumour necrosis factor alpha therapy for ankylosing spondylitis: internationa experience. Ann Rheum Dis 2002;61(suppl 3):iii51-60.

5 Lipsky PE, van der Heijde DM, St Clair EW, Furst DE, Breedveld FC, Kalden JR, et al. Infliximab and methotrexate in the treatment of rheumatoid arthritis. Anti-Tumor Necrosis Factor Trial in Rheumatoid Arthritis with Concomitant Therapy Study Group. N Engl J Med 2000;30:1594-602.

6 Lamprecht P, Voswinkel J, Lilienthal T, Nolle B, Heller M, Gross WL, et al. Effectiveness of TNF-alpha blockade with infliximab in refractory Wegener's granulomatosis. Rheumatology (Oxford) 2002;41:1303-7.

7 Reiff A, Takei S, Sadeghi S, Stout A, Shaham B, Bernstein B, et al. Etanercept therapy in children with treatment-resistant uveitis. Arthritis Rheum 2001; $44: 1411-15$.

\section{Syncope in a patient with relapsing polychondritis W R Saliba, L H Goldstein, G S Habib, M Elias}

$\mathrm{R}$ elapsing polychondritis (RP) is a rare disease, characterised by recurrent episodes of inflammation of cartilaginous tissues and other proteoglycan rich structures. $^{12}$ The cardiovascular system is affected in $24-52 \%$ according to different series, ${ }^{134}$ and typically is not the presenting feature but appears after a mean of six years after the onset of symptoms ${ }^{5}$; aortic regurgitation is the most common manifestation (4-10\%), followed by mitral regurgitation $(2-8 \%)$, aortic aneurysm $(2-7 \%)$, pericarditis $(0-8 \%)$, and conduction disturbances (4-6\%). ${ }^{1367}$ Cardiovascular disease mostly affects male patients and is the second most common cause of death in RP. ${ }^{5}$ All types of atrioventricular conduction defects have been reported in RP. ${ }^{67}$ Godeau described transient complete heart block (CHB) during relapses that required temporary pacing, ${ }^{4}$ suggesting recurrent acute inflammation of the conduction system during relapses. Fibrosis of the conduction system was detected at necropsy in a patient with $\mathrm{CHB}^{8}$

\section{CASE REPORT}

Here we report a case of RP in which the relapse was preceded by true syncope, caused by suspected sinus node dysfunction (SND). To our knowledge, both relapse preceded by syncope and SND have not been previously reported in RP.

A 43 year old woman with RP of six years' duration presented to the emergency room with syncope followed by sudden onset of auricular chondritis and right knee arthritis.

On arrival the patient was alert and complained of pain in the inflamed areas. Her blood pressure was 122/73 $\mathrm{mm} \mathrm{Hg}$, temperature was $37^{\circ} \mathrm{C}$, pulse was regular 33 beats/min (her basal rate was 68 beats/min two months previously). Complete blood count, creatinine, urea, serum electrolytes, 
liver and thyroid function tests were normal. An electrocardiogram showed a regular rhythm 34 beats/min with normal QRS and PR intervals. The rhythm was not affected by carotid sinus massage and an echocardiogram was normal. Her drugs were prednisone, azathioprine, and thyroxine (Eltroxin), and she did not take any drugs known to cause bradyarrhythmia.

Within hours almost all joints were affected, the large and small joints of the arms, hip, knee, ankle, foot, costochondral, sternomanubrial, sternoclavicular, and finally, sacroiliac joints. The auricular chondritis worsened and the right external auditory canal was rapidly affected with severe inflammation that led to almost total occlusion with a large serous discharge. She also developed hoarseness and wheezing as a manifestation of laryngotracheal involvement.

Prednisone and azathioprine doses were increased and analgesics were added, as needed, to relieve pain. Five days later the pulse rate gradually increased. Pulse rate at discharge was 65 beats/min.

\section{DISCUSSION}

The inadequate acceleration in sinus rate in response to severe pain in our patient may indicate SND. Sinoatrial block might also be the cause of this bradycardia and invasive intracardiac recordings are required to differentiate it from sinus bradycardia.

The tachybradia syndrome is also a possibility, although the patient did not complain of palpitations. Vagal response that can cause sinus bradycardia and syncope is less likely in this case because the pain was preceded by syncope, and the heart rate did not recover with pain relief.

The sinus node, similarly to the atrioventricular conduction system, may be affected in RP by acute inflammation that eventually may lead to fibrosis. In conclusion, we have described a patient with RP who had a rapid progressive course. Syncope may be the first manifestation of an RP flare, thus doctors should be aware of this symptom in these patients. Finally, SND in RP warrants further investigation.

\section{Authors' affiliations \\ W R Saliba, L H Goldstein, G S Habib, M Elias, HaemeK Medical Centre, Afula 18101, Israel}

Correspondence to: Dr W R Saliba, HaemeK Medical Centre, Afula 18101, Israel Afula, IL; salibuss@yahoo.com

Accepted 11 March 2003

\section{REFERENCES}

1 McAdam LP, O'Hanlan MA, Bleustone R, Pearson CM. Relapsing polychondritis: prospective study of 23 patients and review of the literature. Medicine (Baltimore) 1976;55:193-215.

2 Trentham DE, Le CH. Relapsing polychondritis. Ann Intern Med 1998;129:114-22.

3 Michet CJ, McKenna CH, Luthra HS, O'Fallon WM. Relapsing polychondritis. Survival and predictive role of early disease manifestations. Ann Intern Med 1986; 104:74-8.

4 Godeau P, Blerty O, Guillevin L, Herson S, Piette JC. The heart in collagen diseases. Ann Med Interne 1985;136:496-512.

5 Mainguene C, Bouhour JB, de Lajarte AY, Dupon H. Cardiovascular complications in chronic atrophic polychondritis: a propose of an anatomoclinical disease: review of the literature. Ann Cardiol Angeiol (Paris) 1991;40:97-102.

6 Barretto SN, Oliveira GH, Michet CJ, Nyman MA, Edwards WD, Kullo IJ. Multiple cardiovascular complications in a patient with relapsing polychondritis. Mayo Clin Proc 2002;77:971-4.

7 Del Rosso A, Petix NR, Pratesi M, Bini A. Cardiovascular involvement in relapsing polychondritis. Semin Arthritis Rheum 1997;26:840-4.

8 Bowness P, Hawley IC, Morris T, Dearden A, Walport MJ. Complete heart block and severe aortic incompetence in relapsing polychondritis: clinicopathologic findings. Arthritis Rheum 1991;34:97-100.

To make space for an increased number of papers in this issue the Indexes and Annual Contents will be published on the web only in January 2004. PDFs of these items will be available without charge and will be accessible at www.annrheumdis.com 